\title{
金属電極間を架橋した単分子の電子輸送現象
}

\author{
藤井 慎太郎・木口 学 \\ 東京工業大学 画 152-8551 東京都目黒区大岡山 2-12-1 \\ (2014 年 11 月 15 日受付；2015 年 1 月 20 日掲載決定)
}

\section{Charge Transport Though Single Molecule Bridging Between Metal Electrodes}

\author{
Shintaro FuJII and Manabu KIGUCHI
}

Tokyo Institute of Technology, 2-12-1 Ookayama, Meguro-ku, Tokyo 152-8551

(Received November 15, 2014 ; Accepted January 20, 2015)

\begin{abstract}
Charge transport though single molecular junctions was investigated by break junction (BJ) technique. In the single molecular junction, a molecule is bounded to two metal electrodes to form metal-molecule hybrid. Due to the low dimensionality and interface effects at the metal-molecule contact in the hybrid system, the junctions display unique electronic properties not found in bulk counterpart. Here we demonstrate two examples of the unique electronic properties found in our recent studies. The first one is the electronic switching functionality that originates from external force-assisted reversible change in the contact geometries on the atomic scale at the metal-molecule interface for pyridine and thiophene junctions. The other one is the long range one-dimensional non-resonant tunneling transport for single $\pi$-stacked junctions. These findings on the unique electronic properties of the single molecular junctions provide fundamental guidance toward potential applications in molecular electronic devices.
\end{abstract}

KEYWORDS : charge transport, molecular junction, mechanically controllable break junction, scanning probe microscopy

\section{1.は じめ に}

単分子が金属電極間を架橋してできた単分子接合は, 分子一つに素子機能を持たせる分子エレクトロニクスへ の応用が期待され注目を集めている。単分子接合は二つ の金属一分子接合界面を有する一次元ナノ構造体であ り，また電極まで含めた分子の新しい物質相と考えるこ ともでき, 孤立分子, バルク結晶とは異なる特徵的な機 能の発現が期待できる。以上のような背景から, 単分子 接合は現在活発に研究が展開されている。単分子接合の 研究は, 1974 年のアビラム, ラトナーらのドナーとア クセプター部位を接続させたモデル分子について，整流 特性が発現することが理論的に提案されたことからス夕 ートする ${ }^{1}$ 。それから 25 年たち, 後に示す Mechanically

E-mail : fujii.s.af@m.titech.ac.jp

E-mail : kiguti@chem.titech.ac.jp controllable break junction $(\mathrm{MCBJ})^{2)}$ を用いることで, Reed らによって実験的にベンゼンジチオール単分子の 伝導度が計測された ${ }^{3)} 。 2003$ 年には Scanning tunneling microscope（STM）を使った簡便な計測法が開発され ${ }^{4)}$, 現在では様々な分子の伝導度が計測され, 単分子トラン ジスタ 5 11), 単分子ダイオード 12 16), 一分子の熱輸 送 ${ }^{17 \sim 22)}$ ，また，単分子接合の計測技術を使って，核酸 塩基識別 ${ }^{23)}$, DNA シーケンサーなど医療分野への展開 も行われている ${ }^{24)}$ 。本稿では, 単分子接合の作製および 評価方法, 分子エレクトロニクス分野における単分子接 合のデバイス化の例として単分子スイッチ, そして, 単 分子計測を電子輸送の基礎過程の解明に展開した研究に ついて解説する。

\section{2. 分子接合の作製方法}

単分子接合はSTM-BJ や MCBJ を用い（Fig. 1（a, b)), 分子存在下で金属接合を機械的に破断することで 
(a) STM-BJ

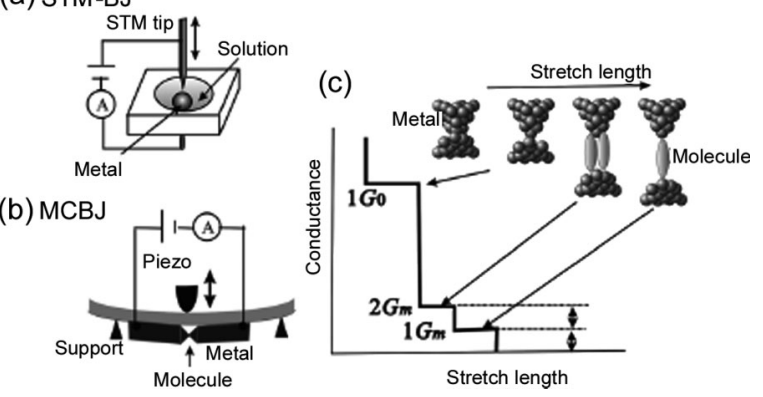

Fig. 1. (a) Schematic illustration of STM-BJ setup in liquid environment. (b) Schematic illustration of MCBJ setup. (c) Conductance versus distance curve during breaking process of $\mathrm{Au}$ atomic contact. The inset indicates schematic illustration of the Au contract during the stretching process. $G_{0}$ and $G_{\mathrm{m}}$ is quantum conductance and molecular conductance, respectively ${ }^{25)}$.

作製することができる。

はじめに，分子を含む溶液中で STM 金属探針を金属 基板に接触させ，ナノサイズの金属接合を形成させる。 続いて, 探針を基板から引き離すと, 金属接合の接触断 面積が段階的に減少し, 最後には金属単原子接合が形成 される。この弾性的な変形過程は, 金属接合の伝導度の 段階的な減少をもたらす。 $\mathrm{Au}$ 金属接合を用いた場合, 単原子接合の伝導度は量子化単位值の $1 G_{0}\left(2 e^{2} / h\right)$ とな る（Fig. 1 (c)）。さらに探針を引き離すと金属単原子接 合は破断し, 電極間にナノギャップが形成される。この 破断過程での探針の変位距離は, 典型的には数ナノメー トル程度である。形成したナノギャップへ溶液内の分子 あるいは電極表面上に吸着していた分子が拡散し, 電極 間を架橋する。金属接合破断直後, ギャップ間隔が狭い ときには多数の分子が電極間を架橋するが, 探針を基板 から引き離すに従って架橋分子数は減少し, 最終的に単 分子接合が形成される。この過程において, 接合の伝導 度を計測すると, Fig. 1 (c) に示すようにある值の整数 倍でステップ状に減少していく様子が観測される。ステ ップの伝導度の差がちょうど 1 分子の伝導度に対応す る。ただし，分子接合中の分子形状や分子一金属界面の 接触状態のばらつきによって伝導度は破断過程ごとに異 なり，ステップの観測される伝導度は摇らぐ。したがっ て，単分子接合の伝導度決定はヒストグラムを用いた統 計的な解析により行われる。

MCBJ 法では絶縁被覆した基板上に事前に中心部分に 切り目を入れた金属線を 2 点で固定する。基板にはリン 青銅などが用いられ，3点曲げの要領で基板を押し曲げ ることで金属線を切れ目を入れた点で破断する。ピエゾ 素子を用いて金属を湾曲させることで, 接合伸長距離を
高精度に制御することができる。単分子接合作製の原理 はSTM-BJ と同じである。最近では微細加工技術で使っ て作製したナノ MCBJ 電極を用いることで，単分子接 合の安定性は飛躍的に向上し, 単分子接合を一週間以上 保持できたという報告もある ${ }^{26)}$ 。

\section{3. 分子スイッチ}

これまで, 電界効果により分子接合がトランジスタ動 作することが報告されているが，チャネル長がナノスケ ールまで小さくなると, 短チャネル効果による移動度の 減少やリーク電流の増加のため, デバイス性能が大きく 低下してしまう。系のサイズがナノスケールまで小さく なると, 既存の動作原理に基づいたデバイス設計が通用 しない。このためナノスケールデバイスに特有の動作機 構の考案およびその動作の実証が求められている。そこ で，分子接合に特有の性質に基づいた抵抗スイッチの開 発を目指した。単分子接合を用いたスイッチを作製する 場合に, 分子骨格を外部摂動によって制御するものと, 金属一分子界面状態を制御する二通りのアプローチを考 えることができる。フォトクロミック分子を用いた単分 子スイッチ ${ }^{27)}$ は前者のアプローチとなる。本研究では, 後者を採用し, ターゲット分子としてまずピラジン分子 に注目した ${ }^{28)}$ 。

ピラジンは分子骨格に二つの窒素分子を有するため, 窒素原子の非共有電子対を介して金属間を架橋すること ができる。また中心の $\pi$ 分子面全体で金属電極間に吸 着することもできる。そこで, これら二つの吸着状態を 外部摂動によって制御することを目指した。

実験は液体 He を用いた極低温超高真空中で MCBJを 用いて行った。Fig. $2(a, b)$ はピラジン導入前後の Pt 接合の破断過程における伝導度変化である。導入前には $\mathrm{Pt}$ 単原子接合に対応する $1.5 G_{0}$ にステップが観測され, ヒストグラムではピークが観測された。ピラジン導入後 には, $1 G_{0}$ および $0.2 G_{0}$ にステップが観測され，ヒスト グラムでも二つのピークが観測された。

続いて, 二つの伝導度を示す分子接合について Inelastic tunneling spectroscopy（IETS）を用いて, その構造解 析を行った。IETS は伝導電子と分子振動の相互作用を 利用した振動分光法である。高伝導度, 低伝導度状態の それぞれについて, IETS 計測を行った結果を Fig. 2 (cf）に示す。高伝導度状態は $60 \mathrm{meV}$, 低伝導度状態では $40 \mathrm{meV}$ に振動モードが観測された。密度汎関数法に基 づいた電子状態計算 (SIESTA) と輸送特性計算 （TranSIESTA）により, 複数の構造モデルについて振動 エネルギーと伝導度を求め, 実験結果と比較すること で, 高伝導度状態ではピラジン平面が電極に対し斜めに 

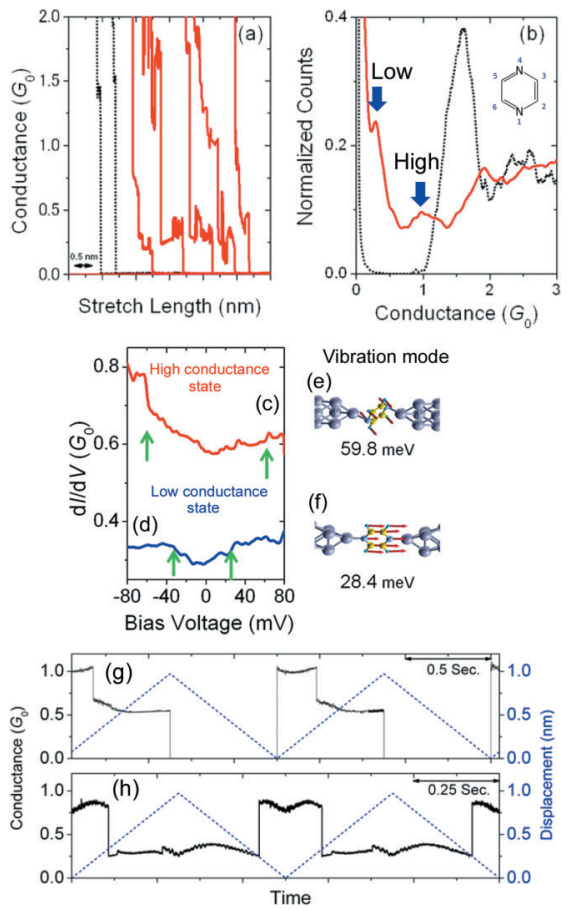

Fig. 2. (color online). (a, b) (a) Conductance traces and (b) conductance histograms of the Pt contacts before (dotted black curve) and after (red curve) the introduction of pyrazine. High and low states are indicated by arrows in (b). The inset represents chemical structure of pyradine (c, d) Differential conductance spectra of single pyrazine molecular junctions for (c) high and (d) low conductance states. The arrows denote shallow symmetric upward features in the differential conductance. Ill-defined features could be ascribed to thermal fluctuation of the junction configuration. (e, f) Theoretical models of the vibrational modes for (e) high and (f) low conducatance states, respectively. (g, h) Switching behavior of a pyridine junction, collected while applying linear ramps (dashed blue line). The displacement is $1.0 \mathrm{~nm}$, and the modulation frequency is (g) 0.8 and (h) $0.4 \mathrm{~Hz}$.

吸着し，低伝導度状態では垂直に吸着していることが明 らかとなった。

二つの伝導度状態が安定に存在することがわかったの で，続いて，外部摂動によって二状態間の可逆なスイッ チング動作について検討を行った。Fig. 2 (g, h) の点線 は電極間距離，実線は接合の伝導度を示す。電極間距離 の狭いときには高伝導度状態，広いときには低伝導度状 態と二状態間を可逆的にスイッチできることが明らかと なった。この単分子スイッチは機械的な摂動により電極 と分子の接合部位の接触状態を変化させることで動作す る，単分子接合に特徵的なスイッチといえる。通常のス ケールの分子結晶に圧力を少しかけた位では伝導度はあ まり変化しないが，本系はわずかな力で動作する点にも 特徴がある。 (a)

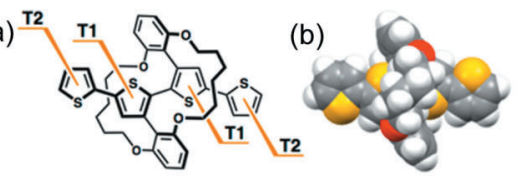

(c)
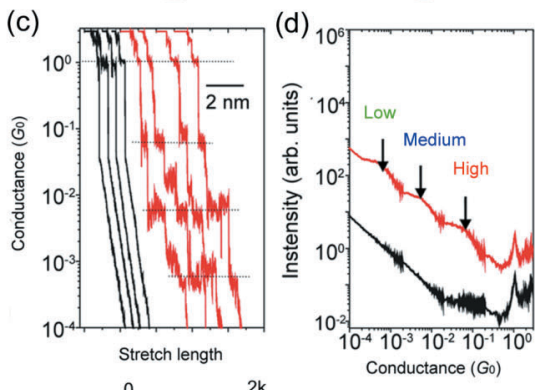

(e)
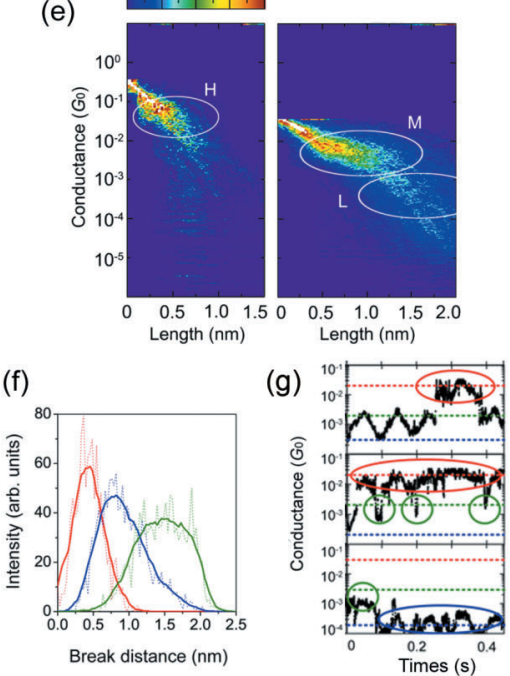

Fig. 3. (color online). (a) Chemical structure and (b) model of QT. (c) Conductance traces of Au contacts in (c) blank solution and (d) solution containing QT molecules (red) (d) Conductance histograms for QT (red) and blank (black). High $(\mathrm{H})$, medium $(\mathrm{M})$ and low $(\mathrm{L})$ conductance states of QT are indicated by arrows. (e) 2-dimensional conductance histograms constructed for $\mathrm{H}$ (red), and $\mathrm{M}$ (blue) and L (black) conductance regimes, respectively. (f) Distribution of break distance of single-molecule junctions of QT. Red, green, and blue curves are results for $\mathrm{H}, \mathrm{M}$, and $\mathrm{L}$ conductance states, respectively. (g) Examples of conductance switching events measured during mechanical elongation/compression process in the presence of QT. Displacement is $0.17 \mathrm{~nm}$ with a stretching speed of $5 \mathrm{~nm} / \mathrm{s}$. Red, green, and blue lines and circles are guides for $\mathrm{H}, \mathrm{M}$, and L conductance states, respectively.

ピラジン単分子接合では, 接合界面の接触状態に着目 したが，今度は，金属と分子の接触位置を制御に基づい た単分子抵抗スイッチ開発へ展開した ${ }^{29)}$ 。多段階スイッ 于能の獲得を視野に入れ, 被覆 Quarter thiophene（QT) をターゲット分子として選択した（Fig. 3 a, b)。チオフ エン環を四つ連結した分子であり，電極と接続できる硫 黄部位が四か所ある。そして, 被覆部位を導入すること 
で，分子がスタックすることを防ぎ，孤立した分子を測 定できるように，そして接続部位を中心の被覆部位から 見て左右の両側で一か所ずつに規定するという役目を持 たせた（隣接した T1-T2 サイトでの接続を防ぐ役割を 持たせた (Fig. $3 \mathrm{a}))$ 。

実験は QT 分子を含むテトラグライム溶液中で STMBJを用いて行った。Fig. $3 \mathrm{c}$ には溶媒中および QT 溶液 中における $\mathrm{Au}$ の接合破断過程における伝導度変化であ る。三つの伝導度領域にステップが観測され，ヒストグ ラムにおいて三つのピークが観測された（Fig. $3 \mathrm{~d}$ )。伝 導度変化の二次元ヒストグラムにおいても三つの領域に 伝導度分布が確認できる（Fig. $3 \mathrm{e} ） 。 2$ 次元ヒストグラ ムとは, 金接合が破断した点を原点として, 接合破断過 程のコンダクタンストレースを重ねたものである。

形成された単分子接合の構造情報を得るために，接合 破断過程に扔ける分子接合長の解析を行った。接合破断 過程において $1 G_{0}$ が破断したときには $0 \mathrm{~nm}$ のギャップ が Au 電極間に形成されている。そこから，伸張した距 離は $\mathrm{Au}$ 電極間のギャップ長に対応する。そこで, High (H), Medium（M), Low（L）の三領域についてギャッ プ長の分布関数を求めた。Fig. $3 \mathrm{f}$ にはギャップ長の分 布関数を示した。その結果， H， M， L におけるギャッ プ長は 0.4，0.9，1.4 nm と求まった。それぞれ T1-T1, T1-T2，T2-T2 の距離 0.4，0.7，1.2 nm とよく対応して おり，H，M，L が電極との接続位置の異なる三つの状 態に対応することが明らかとなった。理論計算により構 造最適化を行ったところ, 吸着サイトは atop サイトで あることも明らかになっている。

本系は三状態を示すことが明らかとなったので，続い てスイッチ動作を検討した。Fig. 3 （g）には電極間距離 を変化させた際の接合の伝導度変化である。三段階を可 逆的に変調する様子が観測できた。以上，分子接合に複 数の接触サイトを導入することで, 接触位置を機械的な 摂動によって動作する多段階抵抗スイッチの作製に成功 した。

\section{4. 電子輸送の基礎過程の解明}

これまでは, 分子エレクトロニクス分野に扔ける分子 接合系の研究を紹介してきたが, 最近では, 単分子計測 技術は，電子輸送の基礎過程を分子レベルで解明する手 法として適用できる。

$\pi$ 共役分子が積層した $\pi$ 積層系の電子伝導は，有機 EL, FET などの有機電子材料, 有機伝導体, ポリマー などの材料系, DNA などの生体系などの様々な分野に おいて重要な電子輸送過程である。これまで $\pi$ 積層系 の電子輸送特性に関してはバルク系で多くの研究が行わ (a)

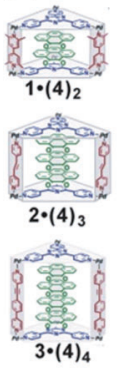

(d)
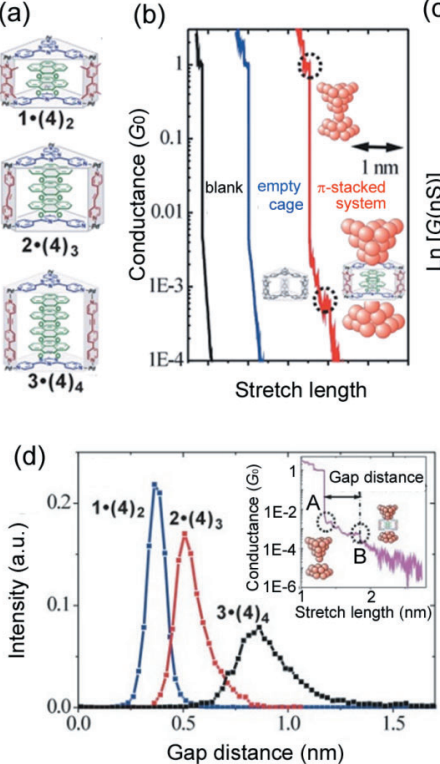

(c)

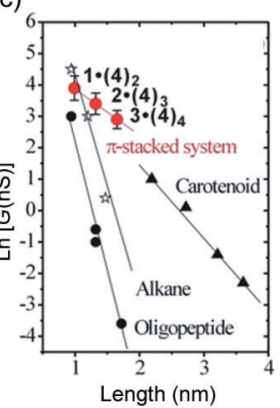

(e)

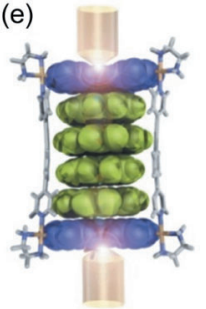

Fig. 4. (color online). (a) Chemical structures of coordination cages 1-3 with different height containing different number of aromatics of 4. (b) Conductance curves for inclusion complex $1 \cdot(4)_{2}$ (red), empty cage 1 (blue), and aqueous blank (black). Dotted circle represent schematic illustration of the junction structure at each point. (c) The distance dependence of observed (exp) and calculated (calcd) conductance $G$ for $\pi$-stacked systems $1 \cdot(4)_{2}, 2 \cdot(4)_{3}$, and $3 \cdot$ (4) $)_{4}$. Typical single-molecule measurements for saturated (alkane chains and peptides) and conjugated (cartenoids) organic molecules. ${ }^{32)}$ (d) Distribution of gap distance of single $\pi$-stacked junctions $1 \cdot(4)_{2}, 2 \cdot(4)_{3}$, and $3 \cdot(4)_{4}$. Inset: Gap distance is defined as length of a conductance plateau. (e) Schematic image of the inclusion complex sandwiched by two Au electrodes.

れているが，積層した $\pi$ 分子を介した電子輸送特性を 単分子レベルで計測した例はなく，その素過程は明らか とはなっていない。 $\pi$ 積層系の電子伝導性を解明するに は, 電極間に制御された枚数の $\pi$ 共役分子を積層させ, その伝導度を計測する必要がある。一方，ナノ電極に $\pi$ 共役分子を導入しても，ランダムに分子は配向し，制御 された形で電極間を架橋させることは困難である。した がって，如何に電極間に $\pi$ 共役分子を制御された形で 積層させるかが鍵となる。

東京大学の藤田誠教授の研究グループは自己組織化過 程を利用して，かご型ホスト分子にゲスト $\pi$ 共役分子 を積層させて内包させる技術を開発している（Fig． 4 a) ${ }^{30)}$ 。ホス卜分子のサイズを制御することで，ねらっ た枚数だけ $\pi$ 分子を内包させることができる。積層分 子数の異なる $\pi$ 積層分子について，単分子接合を作製 し，その伝導度決定を行うことができれば積層した $\pi$ 分子間の電子輸送特性を解明することができる。我々は 
単分子計測技術を $\pi$ 積層分子に適用することで, 積層 した $\pi$ 分子間の電子輸送特性を単分子レベルで解明す ることを目指した ${ }^{31}$ 。

Fig. 4 （b）には $\pi$ 共役分子を 2 枚積層した $\pi$ 積層分子 を含む水溶液中で $\mathrm{Au}$ 接合を破断させた際に観測された 接合の伝導度の伸張距離依存性を示す。Au 単原子接合 の形成㧍よび破断に対応する $1 G_{0}$ に加え, $6 \times 10^{-4} G_{0}$ に 単分子接合形成に対応する伝導度ステップが観測され た。 $\pi$ 分子を内包したカゴ型ホスト分子から $\pi$ 共役分子 を抽出して, かごのみの分子についても伝導度計測を行 った。すると, 溶媒同様, 計測範囲内において伝導度又 テップが観測されず，かご分子の伝導度は検出限界以下 であることがわかった。以上の結果は, 電子が中心の $\pi$ 積層分子を経由して伝導していることを示している。塞 験では, $\pi$ 共役分子を 3 枚, 4 枚含む $\pi$ 積層分子接合に

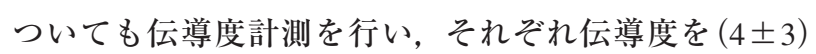
$\times 10^{-4} G_{0}$ に $(2.5 \pm 0.6) \times 10^{-4} G_{0}$ と決定した。積層数の増 加に伴って, 単分子接合の伝導度は緩やかに減少した。

ここで $\pi$ 積層分子の伝導特性を他の分子と比較する。 Fig. 4 (c) は代表的な単一分子ワイヤに扔ける伝導度の 分子サイズ依存性である。いずれも伝導度は分子サイズ に従って減少している。数 $\mathrm{nm}$ 以下の分子接合の場合, 電子はトンネル機構で伝導する。トンネル障壁モデルに おいて, 単分子接合の伝導度 $G$ は接合の長さを $L$ とす ると $G \sim \exp (-\beta \mathrm{L})$ と表現できる。ここで $\beta$ は隇衰定数 である。分子の伝導軌道と電極金属のフェルミエネルギ 一の差に依存し，おおよそエネルギー差が大きいほど $\beta$ は大きな值を示す。減衰定数は電子の輸送しやすさの指 標としてしばしば用いられており, その值が小さいほ ど，より遠くまで電気を流しやすい。非共役系の飽和ア ルカンでは距離に対する伝導度の減衰が大きく $\beta \sim 0.8$ $\AA^{-1}$ である。共役系のカルテノイドでは減衰が小さく $\beta \sim 0.2 \AA^{-1}$ である。本研究で解明した $\pi$ 積層系のデー夕 を同一プロットに示すと, 隇衰が非常に小さく $\beta \sim 0.1$ $\AA^{-1}$ となった。系統的に $\pi$ 積層分子の電気伝導度を計測 することで, 減衰定数を決定し, $\pi$ スタックを介した電 子輸送特性の単分子レベルで解明に成功した。特筆すべ きは, $\pi$ 積層分子はきわめて小さな $\beta$ 值を示し, $\pi$ 分子 間の電荷輸送が優れた伝導であることを示している。

続いて, 単一 $\pi$ 積層分子接合の構造に関する情報を 得るために, 電極のギャップ長と $\pi$ 積層分子サイズの 関連を調べた（Fig. 4 (d) )。 $\pi$ 共役分子を 2 枚， 3 枚，4 枚積層させた分子接合ではギャップ長はそれぞれ 0.37 , $0.51,0.84 \mathrm{~nm}$ となり，打打よそ $0.25 \mathrm{~nm}$ ずつ増加した。 単結晶の $\mathrm{X}$ 線構造解析の結果から分子は積層枚数に従 って $0.30 \mathrm{~nm}$ ずつ増加することがわかっている。ギャッ
プ長と分子サイズの増加分のよい対応は, $\pi$ 積層分子が 上下の $\pi$ 分子 (Fig. 4 e) で接続し, 分子の長軸を電極 方向に揃えた Fig. 4 (e) に示すような構造をとってい ることを示している。以上, 自己組織化法と MCBJ 法 を組み合わせることで, 積層した $\pi$ 分子間の作製とそ の電子輸送過程を単分子レベルで解明することに成功し た ${ }^{31)}$ 。

\section{5. を め}

本稿では, 最近の成果を中心に 1）単分子接合の作製 法, 2) 分子エレクトロニクス分野に扔ける単分子接合 の機能化の例として単分子スイッチ, そして, 3）単分 子計測分野における物資輸送の基礎過程解明に関する研 究について紹介した。

微弱な機械的外部摂動により, 金属一分子界面状態を 原子スケールで制御することで, 界面状態に鋭敏に応答 する伝導度の ON-OFF スイッチおよび多段階スイッチ が実現に成功したが，分子接合系の持っている可能性を 最大限引き出しているとは言い難い。ナノサイズの分子 一金属複合体である分子接合系では，表面・界面（状 態）の発生や, 構造の次元性低下に伴い, 化学活性・外 部摂動に対する応答性・輸送機構などが，バルクとは大 きくかけ離れているため, いかにして新しい動作原理に 基づく機能性を獲得させるかが今後の課題である。

物資輸送の基礎過程解明に関する研究では, 単一 $\pi$ スタックを介した電荷輸送過程に着目したが，いかにし て望み通りの接合構造を創り出すかが鍵であった。自己 組織化ホストゲスト系の化学の力を借りて, ホスト分子 の孤立空間に単一分子を集積化することで，はじめてそ の解明に成功した。しかし分子配線技術に関しては害用 に耐え得る有効な技術がないのが現状であり，分子デバ イスの害用化に向けて配線技術のブレークスルーが切望 されている。

\section{謝辞}

単分子接合の研究は北海道大学理学研究院化学部門村 越敬教授研究室ではじめた研究であり, 東京大学藤田誠 教授, 東京大学渡邊聡教授, 多田朋史准教授, 東京工業 大学理工学研究科化学専攻の学生をはじめとする多数の 方々との共同研究の成果である。記して謝意を申し上げ る。また本研究は科学研究費補助金(新学術領域研究, 基盤研究 A), 旭硝子財団より支援を得て研究を行った。

\section{文献}

1) A. Aviram and M.A. Ratner : Chem. Phys. Lett. 29, 277 (1974). 
2) J.M. van Ruitenbeek et al. : Rev. Sci. Instrum. 67, 108 (1996).

3) M.A. Reed, C. Zhou, C.J. Muller, T.P. Burgin and J.M. Tour : Science 278, 252 (1997).

4) B.Q. Xu and N.J. Tao : Science 301, 1221 (2003).

5) S. Kubatkin, A. Danilov, M. Hjort, J. Cornil, J. Brédas, N.S. Hansen, P. Hedegård and T. Bjørnholm : Nature 425, 698 (2003).

6) B. Xu et al. : J. Am. Chem. Soc. 127, 2386 (2005).

7) I.V. Pobelov, Z. Li and T. Wandlowski : J. Am. Chem. Soc. 130, 16045 (2008).

8) B. Capozzi et al. : Nano Lett. 14, 1400 (2014).

9) F. Chen et al. : Nano Lett. 5, 503 (2005).

10) J. Park et al. : Nature 417, 722 (2002).

11) H. Song et al. : Nature 462, 1039 (2009).

12) M. Elbing et al. : Proc. Natl. Acad. Sci. U.S.A 102, 8815 (2005).

13) G.M. Morales et al. : J. Am. Chem. Soc. 127, 10456 (2005).

14) I. Díez-Pérez et al. : Nat. Chem. 1, 635 (2009).

15) E. Lörtscher et al. : ACS Nano 6, 4931 (2012).

16) A. Batra et al. : Nano Lett. 13, 6233 (2013).

17) P. Reddy, S.-Y. Jang, R.A. Segalman and A. Majumdar : Science 315, 1571 (2007).

18) J.R. Widawsky, P. Darancet, J.B. Neaton and L. Venkataraman : Nano Lett. 12, 354 (2012).

19) S. Guo, G. Zhou and N. Tao : Nano Lett. 13, 4326 (2013).

20) C. Evangeli, K. Gillemot, E. Leary, M.T. González, G. Rubio-Bollinger, C.J. Lamber and N. Agraït : Nano Lett.
13, 2141 (2013).

21) S.K. Lee, T. Ohto, R. Yamada and H. Tada : Nano Lett. 14, 5276 (2014).

22) T. Morikawa, A. Arima, M. Tsutsui and M. Taniguchi : Nanoscale 6, 8235 (2014).

23) M. Tsutsui, M. Taniguchi, K. Yokota and T. Kawai : Nat. Nanotechnol. 5, 286 (2010).

24) T. Ohshiro, K. Matsubara, M. Tsutsui, M. Furuhashi, M. Taniguchi and T. Kawai : Sci. Rep. 2, 501 (2012).

25) M. Kiguchi, S. Miura, K. Hara, M. Sawamura and K. Murakoshi : Appl. Phys. Lett. 89, 213104 (2006).

26) See, for example, D. Dulic', F. Pump, S. Campidelli, P. Lavie, G. Cuniberti and A. Filoramo : Angew. Chem. Int. Ed. 48, 8273 (2009).

27) See, for example, D. Dulic', S.J. van der Molen, T. Kudernac, H.T. Jonkman, J.J.D. de Jong, T.N. Bowden, J. van Esch, B.L. Feringa and B.J. van Wees : Phys. Rev. Lett. 91, 207402 (2003).

28) S. Kaneko, C. Motta, G.P. Brivioand and M. Kiguchi : Nanotechnology 24, 315201 (2013).

29) M. Kiguchi, T. Ohto, S. Fujii, K. Sugiyasu, S. Nakajima, M. Takeuchi and H. Nakamura: J. Am. Chem. Soc. 136, 7327 (2014).

30) Y. Yamauchi, M. Yoshizawa, M. Akita and M. Fujita : J. Am. Chem. Soc. 132, 960 (2010).

31) M. Kiguchi, T. Takahashi, Y. Takahashi, Y. Yamauchi, T. Murase, M. Fujita, T. Tada and S. Watanabe : Angew. Chem. Int. Ed. 50, 5708 (2011).

32) N.J. Tao : Nat. Nanotechnol. 1, 173 (2006). 